\title{
Hubungan Efektivitas Pengawas Menelan Obat (PMO) dengan Keberhasilan Pengobatan Penderita TB Paru di Puskesmas Padasuka Bandung Tahun 2014
}

\author{
Relation of Supervisor Effectiveness Swallowing The Drug with The Efficacy \\ Medication of Tuberculosis Patient in Puskesmas Padasuka Bandung 2014
}

\author{
Upik Rahmi \\ Departemen Keperawatan Medikal Bedah, \\ Program Studi D3 Keperawatan Universitas Pendidikan Indonesia
}

Korespondensi :

Upik Rahmi

Email :upikrahmi@upi.edu

\begin{abstract}
Abstrak
Latar belakang : Penyakit Tuberkulosis Paru (TB Paru) adalah suatu penyakit infeksi kronik yang mengenai jaringan paru yang disebabkan oleh kuman Mycobacterium tuberculosis dan penyakit ini dapat menyebabkan kecacatan fisik dan sosial serta dapat mempengaruhi kehidupan sosial ekonomi penderita. Penelitian ini bertujuan untuk mengetahui hubungan efektifitas Pengawas Menelan Obat (PMO) dengan keberhasilan pengobatan penderita TB Paru di wilayah kerja Puskemas Padasuka Bandung.

Metode : Penelitian ini adalah penelitian deskriptif analitik dengan pendekatan cross-sectional. Populasi dalam penelitian ini adalah penderita TB Paru BTA (+) yang memiliki PMO dan telah menjalani pengobatan 6 bulan dengan jumlah 40 responden menggunakan Teknik Total Sampling. Penelitian ini dilakukan di wilayah kerja Puskemas Padasuka Bandung Tahun 2014.

Hasil : Dari 40 responden sebagian besar yaitu 31 (77.5\%) efektif dalam pengawasan menelan obat dan 26 responden (65\%) berhasil (sembuh). Hasil analisa menunjukkan ada hubungan yang signifikan antara efektifitas pengawas menelan obat (PMO) dengan kesembuhan penderita TB paru ( $P$ value $=0,002$, nilai POR $=9,341$ ).

Kesimpulan : Ada hubungan yang signifikan antara efektifitas kegiatan PMO dengan keberhasilan pengobatan penderita TB paru

Kata Kunci : PMO, Efektifitas, Keberhasilan Pengobatan, Penderita TB paru.

Abstract

Background: Pulmonary TB is a chronic infectious disease affecting the lung tissue caused by Mycobacterium tuberculosis, and the disease can lead to physical disability and social development and can affect the social and economic life of the patient. This study aims to determine the relationship of the effectiveness of the Supervisory Swallowing Drugs to the successful treatment of pulmonary TB patients in the region of Puskemas Padasuka Bandung.

Methods: The study was a descriptive analytic research with cross-sectional approach. The population in this study are patients with TB BTA (+) which has been undergoing treatment PMO and 6 months with the number of 40 respondents using total sampling technique. This research was conducted in the working area Puskemas Padasuka Bandung 2014.

Results: Of the 40 respondents most of which 31 (77.5\%) effective in monitoring dope and 26 respondents (65\%) managed (cured). The analysis shows no significant correlation between the effectiveness of a treatment supporter (PMO) to cure pulmonary tuberculosis patients (pvalue $=0.002$, the value of POR $=$ 9.341).
\end{abstract}


Conclusion: there is a significant correlation between the effectiveness of the PMO with the successful treatment of pulmonary tuberculosis patients.

Keyword : PMO, Efektifitas, Efficacy of Medication of Patient Tuberculosis.

\section{Pendahuluan}

Penyakit Tuberkulosis Paru (TB Paru) adalah suatu penyakit infeksi kronik yang mengenai jaringan paru yang disebabkan oleh kuman Mycobacterium tuberculosis, dan penyakit ini dapat menyebabkan kecacatan fisik dan sosial serta dapat mempengaruhi kehidupan sosial ekonomi penderita. Program yang dilaksanakan secara intensif kejadian penyakit tuberkulosis di Indonesia sudah sangat menurun, tetapi beberapa tahun terakhir ini penyakit TB paru kembali meningkat secara cepat (reemerging disease) yang perlu mendapatkan perhatian dari semua pihak. Indonesia merupakan negara peringkat lima penderita TB paru berdasarkan data organisasi kesehatan dunia WHO yang dirilis pada tahun 2008. Penanganan TB paru setiap lembaga kesehatan harus melakukan metode DOTS (Direct Observe Treatment Shortcourse) atau observasi langsung untuk penanganan jangka pendek. ${ }^{1,2,3}$

Kegagalan pengobatan menurut Soeparman terdapat beberapa faktor yang dapat menyebabkannya, yaitu Obat, Drop-out : kekurangan biaya pengobatan, merasa sudah sembuh, malas berobat/kurang motivasi dan Penyakit seperti lesi paru yang sakit terlalu luas/sakit berat, penyakit lain yang menyertai tuberkulosis. Kegagalan pengobatan yang terbanyak adalah karena kekurangan biaya pengobatan atau merasa sudah sembuh/kurang motivasi. Kegagalan pengobatan ini dapat mencapai 50\% pada terapi jangka panjang karena sebagian besar penderita TB paru adalah golongan kurang mampu sedangkan pengobatan tuberkulosis memerlukan waktu lama dan biaya yang banyak. ${ }^{1,4}$

Keberhasilan pengobatan TB sangat ditentukan oleh adanya keteraturan minum obat anti tuberkulosis, hal ini dapat dicapai dengan adanya pengawas menelan obat (PMO) yang memantau. PMO sangat penting untuk mendampingi penderita agar dicapai hasil yang optimal. Walaupun semua pihak sudah dilibatkan dalam pelaksanaan program DOTS di Wilayah kerja Puskesmas Padasuka tetapi angka kesembuhan TB masih di bawah target nasional. Dikarenakan PMO memiliki peran yang sangat penting dalam mencapai kesembuhan penyakit TB maka peneliti perlu meneliti hubungan efektivitas 
pengawas menelan obat (PMO)

dengan keberhasilan pengobatan

penderita TB paru di puskesmas

padasuka bandung. 5,6

\section{Metode}

Penelitian ini adalah deskriptif analitik dengan desain pontong lintang. Penelitian ini dilakukan pada tahun 2014 di wilayah kerja Puskesmas Padasuka Bandung. Populasi penelitian adalah penderita TB Paru BTA (+) yang memiliki PMO yang telah menjalani pengobatan 6 bulan di wilayah kerja Puskesmas Padasuka Bandung berjumlah 40 penderita. Sampel diambil dengan teknik total sampling. Kriteria inklusinya adalah penderita TB (+) beserta PMOnya yang tercatat di Puskesmas Padasuka, mengambil obat selama 6 bulan berturut-turut atau lebih sebelum masa pengobatannya selesai, dinyatakan conversi bacteriologis dan sembuh. Data sekunder dalam penelitian ini diambil dari register TB 01 dan TB 03 dan data primer dengan kuesioner. Instrumen penelitian yang digunakan terlebih dahulu dilakukan uji validitas dan reliabilitas terhadap 10 penderita TB paru di Puskesmas. Analisa data dilakukan secara univariat dan bivariat dengan uji chi square.

\section{Hasil}

Efektifitas Pengawas Menelan Obat (PMO) dalam penelitian ini dinilai berdasarkan pengawasan pasien TB Paru, kegiatan motivasi pasien dan kegiatan penyuluhan. Identifikasi berdasarkan pengawas pasien TB paru diketahui dari 40 responden sebagian besar yaitu 31 (77.5\%) efektif dalam pengawasan menelan obat, dimana 30 (75\%) efektif dalam kegiatan pengawasan pasien TB paru, 36 (90\%) efektif dalam pemberian motivasi pasien TB paru, dan 37 (92.5\%) efektif dalam penyuluhn TB paru. Hasil menunjukkan bahwa dari 40 penderita TB paru 26 responden (65\%) berhasil (sembuh). Gambaran kegiatan PMO dan keberhasilan pengobatan Tb Paru terdapat dalam tabel 1. 
Tabel 1. Kegiatan Pengawasan Menelan Obat (PMO) dan Keberhasilan Pengobatan TB Paru ii Puskesmas Padasuka Bandung

\begin{tabular}{|c|c|c|}
\hline Kegiatan & Frekuensi & Persentase (\%) \\
\hline $\begin{array}{l}\text { Pengawas menelan Obat (PMO) } \\
\text { Efektif } \\
\quad \text { Tidak efektif }\end{array}$ & $\begin{array}{c}31 \\
9\end{array}$ & $\begin{array}{l}77,5 \\
22,5\end{array}$ \\
\hline $\begin{array}{l}\text { Pengawasan pasien TB paru } \\
\text { Efektif } \\
\quad \text { Tidak efektif }\end{array}$ & $\begin{array}{l}30 \\
10 \\
\end{array}$ & $\begin{array}{l}75 \\
25 \\
\end{array}$ \\
\hline $\begin{array}{l}\text { Motivasi pasien TB paru } \\
\text { - Efektif } \\
\text { - Tidak efektif }\end{array}$ & $\begin{array}{c}36 \\
4 \\
\end{array}$ & $\begin{array}{l}90 \\
10 \\
\end{array}$ \\
\hline $\begin{array}{l}\text { Penyuluhan pasien TB paru } \\
\text { - Efektif } \\
\text { - Tidak efektif }\end{array}$ & $\begin{array}{c}37 \\
3\end{array}$ & $\begin{array}{c}92,5 \\
7,5\end{array}$ \\
\hline $\begin{array}{l}\text { Keberhasilan pengobatan } \\
\text { - Sembuh } \\
\text { - Tidak sembuh }\end{array}$ & $\begin{array}{l}26 \\
14 \\
\end{array}$ & $\begin{array}{l}65 \\
14 \\
\end{array}$ \\
\hline
\end{tabular}

Hasil penelitian menunjukkan bahwa 40 responden yang mendapatkan kegiatan PMO secara efektif ada $24(77,4 \%)$ responden yang dinyatakan sembuh dan 7 $(22,6 \%)$ responden tidak sembuh serta jumlah responden yang mendapat kegiatan PMO yang tidak efektif ada $2(22,2 \%)$ responden sembuh dan 7 (77,8\%) responden tidak sembuh. Hasil uji chi square dipeoleh nilaiai Pvalue sebesar 0,002. Dengan demikian disimpulkan bahwa terdapat hubungan yang signifikan antara efektifitas pengawas menelan obat (PMO) dengan keberhasilan pengobatan penderita TB paru di Puskesmas Padasuka Tahun 2014. Nilai POR $=$ 9,341 yang berarti penderita TB paru yang mendapat kegiatan $\mathrm{PMO}$ yang efektif berpeluang untuk sembuh 9,341 kali dibandingkan dengan penderita TB paru yang mendapatkan kegiatan PMO tidak efektif. Hasil analisis dapat dilihat pada tabel 2 .

Tabel 2. Efektifitas Kegiatan Pengawasan Menelan Obat (PMO) dengan Keberhasilan Pengobatan TB Paru di Puskesmas Padasuka Bandung

\begin{tabular}{|c|c|c|c|c|c|c|c|c|}
\hline \multirow[t]{3}{*}{ Efektifitas PMO } & \multicolumn{4}{|c|}{ Keberhasilan Pengobatan } & \multirow{2}{*}{\multicolumn{2}{|c|}{ Total }} & \multirow[t]{3}{*}{ POR } & \multirow[t]{3}{*}{ P Value } \\
\hline & \multicolumn{2}{|c|}{ Sembuh } & \multicolumn{2}{|c|}{ Tidak } & & & & \\
\hline & $\mathrm{n}$ & $\%$ & $\mathrm{n}$ & $\%$ & $\mathrm{~N}$ & $\%$ & & \\
\hline Efektif & 24 & 77,4 & 7 & 22,6 & 31 & 100 & & \\
\hline Tidak efektif & 2 & 22,2 & 7 & 77,8 & 9 & 100 & 9,341 & 0,002 \\
\hline Jumlah & 26 & 49,8 & 14 & 50.2 & 40 & 100 & & \\
\hline
\end{tabular}


Pembahasan

Pengobatan penyakit TB paru harus sesuai dengan strategi DOTS, setiap penderita yang baru ditemukan dan mendapatkan pengobatan harus diawasi menelan obatnya setiap hari agar terjamin kesinambungan dan tercegah dari kekebalan obat atau resistensi yaitu seorang Pengawas Menelan Obat (PMO). Penderita dan PMO harus diberi pelatihan singkat mengenai perlunya pengawasan menelan obat setiap hari, antara lain agar mereka mengetahui gejala-gejala TB paru, tanda-tanda efek samping obat yang dirasakan dan mengetahui cara mengatasi bila ada efek samping, cara merujuknya, pentingnya pemeriksaan dahak ulang, serta cara memberi penyuluhan penyakit TB paru. $^{3}$

Hasil analisis diketahui bahwa terdapat hubungan yang signifikan antara efektifitas kegiatan PMO dengan keberhasilan pengobatan penderita TB paru dimana nilai $\mathrm{POR}=9,341$ artinya penderita TB paru yang mendapat kegiatan PMO yang efektif berpeluang untuk sembuh 9,341 kali dibandingkan dengan penderita TB paru yang mendapatkan kegiatan PMO tidak efektif.

Hal ini sejalan dengan pendapat penelitian Firdaus yang menyatakan terdapat pengaruh peranan PMO terhadap keberhasilan pengobatan penderita TB Paru di wilayah kerja Puskesmas Baki Sukoharjo (Pvalue $=0,002$ ). Penelitian Jumaelah didapat bahwa ada hubungan antara kinerja pengawas menelan obat terhadap keberhasilan pengobatan TB paru dengan DOTS di RSUP Dr. Kariadi Semarang. Strategi baru pengobatan TB yang melibatkan PMO dalam program DOTS dapat meningkatkan keberhasilan pengobatan TB yang tercermin dari meningkatnya angka konversi dan angka kesembuhan serta menurunnya angka drop out. Namun demikian, tidak menutup kemungkinan untuk terjadi kegagalan pada pasien TB dengan kinerja PMO baik. Hal ini dikarenakan faktor yang mempengaruhi kesembuhan TB tidak hanya dari kinerja PMO saja melainkan dari faktor pasien dan faktor lingkungan. ${ }^{7,8}$

Kinerja PMO yang baik akan memotivasi penderita untuk menjalani pengobatan secara taratur sehingga keberhasilan pengobatan dapat tercapai. Sebaliknya jika kinerja PMO buruk dimungkinkan akan mempengaruhi pengobatan pendeita TB menjadi tidak patuh. Maka dari itu kinerja PMO perlu ditingkatkan terutama dalam hal memberikan informasi pada anggota keluarga dengan TB, karena jika informasi tidak disampaikan dikhawatirkan akan 
menyebabkan penularan TB. menelan obat anti tuberkulosis Berdasarkan hasil tersebut, kinerja (OAT). ${ }^{11,12}$

PMO berperan penting dalam meningkatkan angka kesembuhan TB, sehingga diharapkan dengan adanya PMO dengan kinerja yang baik akan meningkatkan angka kesembuhan TB. ${ }^{9}$

Menurut Depkes RI, tugas seorang PMO adalah mengawasi pasien TB agar menelan obat secara teratur sampai selesai pengobatan, memberi dorongan kepada pasien agar mau berobat secara teratur, mengingatkan pasien untuk periksa ulang dahak pada waktu yang telah ditentukan. Mengingat pentingnya tugas yang dilakukan oleh seorang PMO, maka kinerja PMO yang baik akan mempengaruhi kesembuhan pasien. Aditama menyatakan tugas seorang PMO adalah memberikan motivasi (dorongan) kepada penderita agar mau berobat teratur. ${ }^{3,10}$

Pengobatan jangka panjang sangat memerlukan kesabaran dan tingkat kedisiplinan yang tinggi pada penderita TB paru, terkadang tidak menutup kemungkinan penderita TB paru dihinggapi rasa jenuh, bosan dan putus asa, untuk itu dikeberadaan seorang PMO bagi penderita TB paru sangat membantu dalam mengawasi dan memberikan motivasi kepada penderita agar selalu disiplin dalam

\section{Kesimpulan}

Hasil penelitian menunjukkan bahwa kegiatan pengawas menelan obat (PMO) dari 40 responden sebagian besar efektif dan keberhasilan pengobatan penderita TB paru berhasil (sembuh). Ada hubungan yang signifikan antara efektifitas pengawas menelan obat (PMO) dengan kesembuhan penderita TB paru.

\section{Ucapan Terima Kasih}

Penulis mengucapkan terima kasih kepada institusi Puskesmas Padasuka Bandung dan semua pihak yang terlibat atas konstribusi dan bantuan dalam proses pengumpulan data.

\section{Daftar Pustaka}

1. Soeparman. Tuberkulosis Paru. Jilid II. Depok: Balai Penerbit FKUI; 2006.

2. Resmiyati. Hari TB sedunia. Pemerintah Aktif Cari Penderita TB. 2011.

3. Aditama. Tuberkulosis :Diagnosis Terapi dan Permasalahannya. Laboratori. Jakarta; 2006.

4. Walley JD, Khan MA, Newell JN, Khan $\mathrm{MH}$. Effectiveness of the direct observation component of DOTS for tuberculosis: A 
randomised controlled trial in Pakistan. Lancet. 2001;357(9257):664-9.

5. Bambang Sukana, Herryanto S. Pengaruh Penyuluhan Terhadap Pengetahuan Penderita TB Paru Di Kabupaten Tangerang. ejournal litbang [Internet]. 2000; Available from: http://ejournal.litbang.depkes.go.i d/index.php/jek/article/viewFile/53 99/4427

6. Departemen Kesehehatan RI. Profil Kesehatan Indonesia. Jakarta; 2011.

7. Firdaus KMZ. Pengaruh Peranan Pengawas Menelan Obat (Pmo) Terhadap Keberhasilan Pengobatan Tb Paru Di Wilayah Kerja Puskesmas Baki Sukoharjo [Internet]. Universitas Muhammadiyah Surakarta; 2012. Available from: eprints.ums.ac.id/21949/20/NAS KAH_PUBLIKASI.pdf

8. Jumaelah N. Hubungan Kinerja Pengawas Menelan Obat Dengan Keberhasilan Pengobatan TB Paru Dengan DOTS Di RSUP Dr. Kariadi Semarang. Medica Hosp. 2013;2:54-7.

9. Hayati D, Musa E. Hubungan kinerja Pengawas Menelan Obat Dengan Kesembuhan Tuberkulosis di UPT Puskesmas Arcamanik Kota Bandung. J IImu
Keperawatan. 2016;4(1):10-8.

10. Departemen Kesehehatan RI. Pedoman Nasional Penanggulangan Tuberkulosis. Jakarta; 2014.

11. Sedyaningsih. Materi Kuliah Umum Pada Kongres Nasional XII Perhimpunan Dokter Paru Indonesia (PDPI). diselenggarakan di Hotel The Hills Bukit Tinggi Sumatera Barat; 2010.

12. Sutanto. Efektifitas Pengawas Menelan Obat Pada Konversi Dahak Penderita Tuberkulosis Paru, Kajian Antara Petugas Kesehatan dan Tokoh Masyarakat di Pekalongan. Universitas Gadjah Mada; 2000. 